\title{
The Key Drivers of Human Security Discourse and the Challenge to Realism
}

Honorary Research Fellow

La Trobe University, Australia

Editor, Global Change, Peace and Security

Now based in the Centre for Dialogue at La Trobe University, Dr Stephen James studied Arts and Law at the University of Melbourne before completing a PhD in Politics at Princeton University where he was a Princeton Wilson Fellow and Lecturer. In 2006, he was a Visiting Fellow at the Key Centre for Ethics, Law, Justice and Governance at Griffith University. He is the author of Universal Human Rights: Origins and Development (New York: LFB Scholarly Publishing, 2007), edits the journal Global Change, Peace and Security and is on the Editorial Review Board of Human Rights \& Human Welfare. He can be contacted at Stephen.James@latrobe.edu.au.

Recently, earthquakes in Haiti, Chile and New Zealand, mudslides in Brazil, a catastrophic oil spill in the Gulf of Mexico the fallout from the fiscal crisis in Greece, and refugee flows out of Libya have highlighted the continued relevance of non-traditional threats to state and non-state security, and of human security as a lens through which to understand them better. In March 2010 even a former head of the Australian army, Peter Leahy, while criticizing the Australian government's defence spending, described the world as a friend of human security might:

We've also seen the changing nature of threats, from territory and sovereignty to terrorism, transnational criminals, [and] cyber-warfare. We've still yet to figure it cyber-warfare. We've still yet to figure it climate change, pandemics, mass migration, how do we live and deal with that sort of stuff? We also have to deal with failed and Teiling states. We've intervened in a in a number of states in our region and there's an expectation that we should

We need to have a very close look at the most effective tools to use in this new security environment, and my view would s is let's have a look at high-end equipment being procured for the least likely defence eventuality.
Thus, like the rich landscape of contemporary human rights discourse, the world of human security is signposted with many of the leading issues in international affairs, including not just the traditional ones of nuclear weapons and arms control, but also drug and human trafficking, pandemics and health security, climate change and environmental security, population movements, food and water security, poverty and homelessness, genocide, and violence gainst women and gays. ${ }^{2}$

Just as interesting, though not fully explored in this article, has been the way in which the discourse of human security has elicited spirited responses from members of most of the main schools of International Relations (IR) and security theory, including realists, liberals, cosmopolitans, feminists, constructivists and critical theorists.

This short article is drawn from a larger research project exploring the origins of human security discourse, its theory and practice, and its meaning and utility for governments, international and regional organizations, the third sector and civil society. The project also investigates the extent to which human security has been institutionalized and operationalized at various levels of governance. It is funded by an
Australian Research Council Linkage Learned Academies Special Projects grant with the support of the Australian Academy of Social Sciences, the Institute for Human Security at La Trobe University (Melbourne, Australia), and other partners.

In particular, the project explores the meaning and utility of human security as a response to non-traditional threats to states and human beings-threats that have arisen and become more visible to, scholars and policy-makers monitoring a globalizing and interdependent world.

My research as part of this project relies primarily on political science and IR literature to explore the main drivers (the subject of this article), precursors and concepts of human security. I am especially interested in the tense "dialectic" between national and human security, ${ }^{4}$ its overlapping connection with the responsibility to protect (R2P) principle and the ways in which it straddles thinking about peace, development, welfare, human rights and human well-being.

\section{What is human security?}

Influenced by the capabilities approach of the Nobel prize-winning economist Amartya Sen-including its focus on the fundamental importance of freedom to human fulfilment, autonomy and the satisfaction of the full range of basic needsthe Commission on Human Security (CHS), in its impressive report in 2003, defined human security in the following terms:

Human security is concerned with safeguarding and expanding people's vita freedoms. It requires both shielding people from acute threats and empowering people to take charge of their own lives ... Human security complements state security, enhances human rights and strengthens human development ... means protecting people from critical (severe) and pervasive (widespread) threats and institutions.

The CHS synthesizes the themes of freedom from fear and want pervasive in
UN discourse and emphasizes that human security is "people-centred," and must respond to a wide range of "menaces" by making use of many different actors beyond the nation-state. The CHS's report is notable for distinguishing (the nevertheless overlapping) phenomena of human security and human development on the basis that the former is more concerned with "downturn with security" while the latter involves "expansion with equity." This distinction accentuates that any effective human security strategy must protect individuals in crisis. The CHS takes a broad approach to human security examining not only conflict prevention, the protection of civilians (and particularly women, children and those with disabilities) in wartime, disarmament, demobilization and post-conflict reconstruction, but also personal violence and other crime, economic and health security, the needs of refugees, the vulnerability of internally displaced persons and migrants, the importance of public welfare systems ("social protection") and the pivotal role of education. The CHS also begins to connect human security with the norms of R2P, a version of humanitarian intervention. This is evident in the $\mathrm{CHS}^{\prime} \mathrm{s}$ exploration of what infrastructure, resources and governance states need in order to secure their citizens; that is, to be successful rather than "failed" states. It is also reflected in the CHS's endorsement of what has surely become a governing principle of the UN: the conditional nature of state sovereignty. ${ }^{6}$

The key drivers of human security discourse.

Among the key stimulants for the development of the concept of human security are the long-running processes of globalization and interdependence that have affected conceptions of the state, warfare and military defence (to put it crudely), economy and technology, the natural environment, culture and identity, and global and regional governance. While globalization was not born 
in the 1980s, when it became a popular term in IR theory-in other words, globalization has a history of several decades at the very leastover the last few decades the evidence of the uneven acceleration, magnification, dispersal and interaction of the effects of globalization on the security of states and human beings has undermined the plausibility of traditional

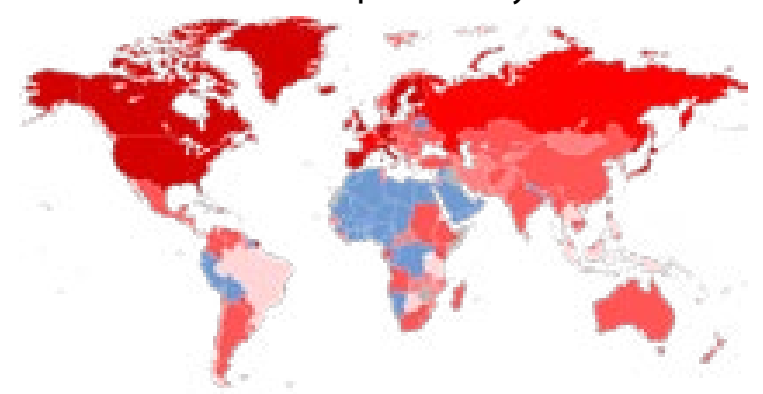

Map of countries affected by current World Financial Crisis. The darkest shaded nations experienced the worst degree of recession.

realist notions of security. The combination of these empirical developments, together with new theoretical perceptions, provided the setting for the emergence of ideas of human security. For it was not only the existence of the phenomena of globalization and interdependence that mattered, but the capacity to see them, and to recognize them as significant, that was crucial. Realists have been blind to enduring threats to security that do not fit within its paradigm: for example, genocide and other human rights violations, poverty and food riots, authoritarianism, violence towards women and racial discrimination.

As Joseph Camilleri has argued ${ }_{1}^{8}$ it is not only the armed attack of one nation-state upon another, using organized military forces, that can cause physical and psychological insecurity for human beings and undermine states. Proponents of human security argue that threats come from a diverse range of sources and actors, that there is a wide variety of possible responses by many different actors to those threats, and that the fundamental purpose of those responses is to secure human beings, not the state. The rationale for human security embodies a number of claims:

Internal sources of insecurity for people and states are as important as external ones.

The aspects of people's and states' security that can be threatened are complex and multidimensional: they can be objective (for example, environmental integrity, life and limb, nutrition and health), subjective (for example, emotional well-being, economic confidence, perceptions of government legitimacy) or a combination of the two.

There is a wide variety of military and nonmilitary threats to the security of human beings and states. These threatening forces involve diverse agents and causes, including non-state (or "transnational"9) actors interacting with national, international, global, regional and local developments in, for example, economic, environmental, political, cultural and technological fields.

Insecurities are dynamic and interactive (for example, political repression may increase the likelihood offamine; economic insecurity can undermine health; global warming can produce climate change refugees; population flows can contribute to economic insecurity, environmental degradation, violent conflict and disease). The state can not only enhance security (for example, by national defence, provision of public goods, legal regulation, opportunities for political participation) but also be a major threat to it (for instance, by killing, torturing and imprisoning people, by coercive programs of economic modernization, by provoking war with other states, and by corrupt administration).

Even states with the best of intentions have limited capacities to provide security for their citizens, other human beings or even their state (for example, structural adjustment conditions might reduce the capacity of a state to provide for healthcare; a state might be unable to combat a regional or global financial crisis; a state will often be ill-equipped to deal with global, borderless, threats to its natural environment).

\section{Human security and the}

challenge to realism

$$
\text { How do }
$$

-evident in

to the state, war and defence, economy, technology, environment, identity and culture, and global and regional governance - render realist claims empirically dubious and normatively undesirable? First, there is ambiguity about whether the term "state" means the government, nation or nationstate. ${ }^{10}$ Globalization has been joined by fragmentation as, for instance, ethno-nations trapped within the borders of a nation-state seek independence or at least autonomy. Second, the realist assumption of the state's monopoly on the loyalty of its residents, and even citizens, based on a homogeneous

The effects of globalization on the security of states and human beings have undermined the plausibility of traditional realist notions of security.

nationalism is usually falsified by competing local, tribal, ethno-nationalist, multicultural, religious, cultural and transnational identities. Moreover, these alternative identities are facilitated by porous borders through (or outside of) which various cultural influences flow, aided by television, radio, the internet and YouTube. Third, the realist approach overestimates the ability of states to solve national, let alone global, problems. Finally, the realist approach neglects how states work with and have their sovereignty constrained (and sometimes enhanced) by various non-state agents such as International Governmental Organizations (IGOs), NGOs, International Non-governmental Organizations (INGOs) social movements and other individuals and collectivities."

Peter Willetts has pointed out that while there are around two hundred governments in the world, there are more than seventy thousand transnational corporations (TNCs), roughly ten thousand national NGOs and more than seven thousand INGOs. He concludes that these numbers suggest that policies and decisions are made by various transnational actors within "complex systems" that are much richer than the interstate world that realists assume. ${ }^{12}$ Likewise, Scholte, Camilleri and Slaughter have identified the constraints and opportunities that the bewildering range of global, supranational, transnational, international and regional organizations, institutions and regimes present to nation-states. These systems can positively or adversely affect and respond to the requirements of human security in all its complexity. They provide opportunities for advocacy, cooperation, coordination, confidence-building,regulation, harmonizaton, and subsidiarity, the pooling of sovereignty and the adjudication and enforcement of sanctions. ${ }^{13}$ In this "complex multilateralism" (one augmented by emerging multipolar configurations: for example, the consolidation of the European Union, the rise of China and India) states become, in Slaughter's words, "overlaid by non-state actors." ${ }^{14}$

In relation to two of the preoccupations of realism, military defence and warfare, it is clear that the security of human beings and states can be threatened by a state's preparation for war. A state's efforts to enhance its national security by preparing for war can undermine human security due to the distortion of the economy: what might be called a war deficit (spending on military hardware, for example) takes resources away from satisfying vital human needs like food, housing and health. The preparation for war often involves coercion, restriction of civil liberties, and economic adversity. Also, the security of states and human beings can be undermined as much by internal threats (for example, civil wars, ethnic cleansing, 
secessionist conflicts, riots, coups d'état, to many people, often aggravated by national revolutions, and sectarian battles) as by conscription schemes. ${ }^{16}$

external ones. These threats also demonstrate that there is no necessary correlation between a state's clear and well-defended external borders and societal security (Northern Ireland, Zimbabwe and South Africa are good examples). ${ }^{15}$

Security for a state or nation does not mean security for (all) its inhabitants:

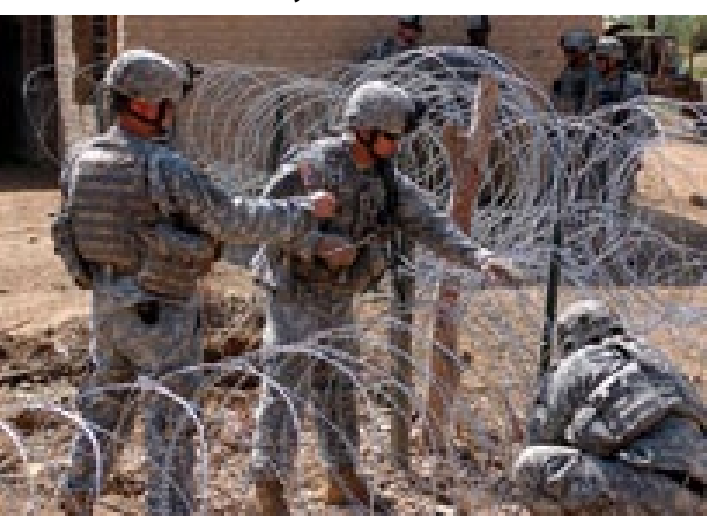

United States soldiers build a security fence in Muehla, Iraq.

poverty, persecution, repression, and disease may remain endemic within it. But states have a reduced capacity even to defend their external borders given the proliferation of extremely destructive conventional arms, as well as nuclear and other weapons of mass destruction (WMD). The risks associated with these weapons are increased by the possibility that they will be used accidentally, without state authority, or cause harm while being transported, stored or dumped. Defensive territoriality and sovereignty are also eroded by the location of foreign military bases on state soil, as military autonomy is constrained through joint military exercises, shared intelligence, coordinated strategies and command structures. The enormous financial cost of maintaining and upgrading military force for any one state has led to what Camilleri calls the "transnationalization of defence" in relation, for example, to the production of military hardware and the pursuit of research and development. Obviously, waging wa causes loss of life, injury, anxiety and trauma
Michael Sheehan, drawing upon the work of Mary Kaldor and Lawrence Freedman, has identified aspects of "new wars" that challenge the simplistic model of interstate, nationalistic, territorial battles between regular forces in defence of their nations' security. War increasingly involves many non-state actors (for example, mercenaries, advisers, media representatives, humanitarian NGOs and INGOS); campaigns fought in cyberspace and via worldwide media; weaker parties in asymmetrical wars trying to shock and demoralize their opponents' publics (the Mogadishu effect) rather than necessarily to seize state power, or even to 'win'; the outsourcing and privatization of military functions, including logistics, security, equipment and training; cultural motivations, such as fighting for a religious cause and/or to resist Western secularism; sub-state threats from, for instance, militias, paramilitaries, criminals, warlords, tribes, and security TNCs; and the decentralized funding of war through kidnappings, money laundering and the trafficking of drugs, arms, and people."

Consistent with these conclusions about new warfare, James Kiras's work has demonstrated that globalization, particularly the emergence of new technologies, has made terrorist actions and messages by non-state actors more efficient, mobile, simultaneous, instantaneous, widespread and destructive than the first phase of international terrorism of the 1960s. Al Qaeda, for example, has been described as a global network of franchise operations that uses the media, the internet, "distance learning," improved transport systems and personal electronics, local sympathizers and "homegrown" terrorists to threaten and carry out simultaneous attacks in different parts of the world. ${ }^{18}$

The globalization of the economy and associated technologies, including those affecting transportation and the carrying of goods, have also reduced the importance of territorial space and challenged the economic, social and political security and autonomy of nation-states. This trend is only emphasized by the ongoing ramifications of the Global Financial Crisis (GFC).

As Jan Art Scholte has argued, there has been, first, an increased volume of money, goods, people and investments crossing borders (internationalization). Second, national borders have become more open, partly in response to neoliberal pressures and prescriptions from the World Trade Organization (WTO) and other bodies (liberalization). Third, borders are often transcended in regard to trade and finance (the "transborder economy"). These supraterritorial and "transplanetary" tendencies, to use Scholte's labels, have rendered the notion of isolated national economies under the absolute direction of their governments fictitious. ${ }^{19}$

With regard to trade, we may note, for example, the following features:

the prominence of "transborder production" the global sourcing of components and labour, worldwide factories, trade within global TNCs, preferential economic zones such as the maquiladora region in Mexico-USA. ${ }^{20}$

- the phenomenon of "regulatory arbitration": global TNCs leveraging states by threatening to move their operations elsewhere. ${ }^{21}$

- the challenges of extraterritoriality and the conflict of laws that reduce the relevance and impact of national jurisdiction and regulation. ${ }^{22}$

- the rise of global, remote electronic commerce (for example, eBay, Amazon Books).

These developments can reduce the capacity of states to enforce human rights (for example, privacy and labour standards) and environmental standards, as well as their criminal laws (for example, regarding pedophilic pornography on the internet).

The impact of the globalization of finance was notoriously on display during the 1997 Asian financial crisis and with the onset and ramifications of the GFC in 2008. Some important aspects of the globalization of finance include ${ }^{23}$ :

the globalization of money and credit arrangements: the ubiquity of the nowdeclining US dollar and "dollarization," the Euro, foreign exchange dealing, smart and credit cards.

"[t]ransplanetary banking": transborder deposits and loans, global instantaneous electronic funds transfers between banks. global securities and investment: "transplanetary securities" such as euroequities, Eurobonds; global funds 24hour global, electronic trading of bonds, shares, derivatives, futures and options; the influence of investors on regulation.

Additionally, globalization is evident in the spread of human rights, in the rise of new transnational social movements, such as the peace movement, in the dramatic increase in the number of NGOs and in the ways that mass travel and almost instantaneous transborder communication foster these developments. Thus, so the argument goes, more of us might become empathic cosmopolitans and be more sensitive to the welfare of strangers in distant lands. ${ }^{24}$

And yet Scholte is right to emphasize, in response to the "hyperglobalists," that economic "globalization has repositioned the (territorial) state" rather than brought about its extinction. The state continues to be an important economic actor, participating in, rather than simply passively affected by, global processes. Economic globalization has been uneven, territorial space remains significant (for example, with regard to manufacturing, retail banking, locally-based corporations and national stock), and state decisions can affect the impact of globalization by regulating money flows, interest rates, TNCs, offshore finance and standards relating to human rights, labour and the environment. ${ }^{25}$

Nevertheless, human

security $\square 0$ 
discourse illuminates many features of global realists miss when they myopically focus on politics, economy and culture that traditional relations between sovereign states.

Acknowledgements

This article, in revised form, is drawn from a larger working paper: "Human Security: Key Drivers, Antecedents and Conceptualization." (Working Paper No. 1, Institute for Human Security, La Trobe University, 2010:

<http://Www.latrobe.edu.au/humansecurity/assets/downloads/HHS-WP-01-James.pdf>),

The research was supported by a research fellowship in the Institute for Human Security, La Trobe University al Sciences.

I also thank the editor of CIAR for his valuable suggestions.

Endnotes

.

(Working

Paper No. 1, Institute for Human Security, La Trobe University, 2010:

Shttp://www.latrobe.edu.au/humansecurity/assets/downloads/HS-WP-01-James.pdf $>$ ).

For a very useful introduction to the range of theoretical perspectives on human security,

see the special issue of Security Dialogue 35, no. 3 (September 2004)

Dan 2003/2

Commission on Human Security, Human Security Now (New York: Commission on Human Security, 2003), iv, 2, 4

Ibid., 6, 9, 12, and passim.

"Whe Sheehan, "The Changing Character of War," John Baylis, "International and Global Security," Ngaire Woods, "International Political Economy in an Age of Globalization," Richard Little, "International Regimes," "Peter Willetts, "Transnational Actors and International
Organizations in Global Politics," John Vogler "Environmental Issues," James T Kiras "Terrorism and Globalization", Edward Best and Thomas Christiansen, "Regionalism in International Affairs," Jan Aart Scholte, "Global Trade and Finance," Caroline Thomas, "Poverty, Development, and Hunger," and lan Clark, "Globalization and the Post-Cold War Order," in John Baylis, Steve Smith and Patricia Owens (eds), The Globalization of World Politics: An Introduction to International Relations 4th edn (Oxford: Oxford University Press, 2008), Chs 12

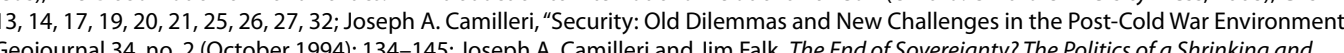
. (eds), An Introduction to International Relations: Australian Perspectives (Melbourne: Cambridge University Press, 2007), Ch 25. thank Joseph Camilleri for the structure employed here to examine the drivers of the development of the human security concept. "Willetts, "Transnational Actors," 332 Actors," $331-332$.

Scholte, "Global Trade and Finance"; Camilleri, "Security"; Slaughter, "Globalisation.

"Slaughter, "Globalisation," 303; Camilleri, "Security," 139-144; Scholte, "Global Finance and Trade"

452; Best and Christiansen, "Regionalism"; Willetts, "Transnational Actors"

${ }^{15} \mathrm{Camil}$
${ }^{16} \mathrm{lbid}$.
${ }^{17}$ Sheehan

Sheehan, "The Changing Character of War"; Willetts, "Transnational Actors," 337.

"Kiras, "Terrorism"; Willetts, "Transnational Actors,", 338.

(

tional Actors," 335

"Willetts, "Transnational Actors," 335; Woods, IInternational Political Economy," 253.

2 Ibid., 336

In what follows, I rely on Scholte, "Global Trade and Finance," 459-462.

It thank Robyn Eckersley for drawing my attention to these concerns.

Photos courtesy of:

http:///com
Adapt-Qaeda: Analyzing the Relationship Between

Ideology, Organizational Transformation, and

the Exploitation of Information Technology

BA Political Science and Economics

Rutgers University, 2010

This paper traces and analyzes the organizational evolution of al-Qaeda from the late 1980s to the present day. It notes that al-Qaeda initially exhibited a hierarchical system and then adopted a hub network approach. Following 9/11 and the U.S assault in Afghanistan, the environment surrounding al-Qaeda was drastically altered, and thus organizational changes became necessary. Employing the concept of a "dune" organization to explain the unique and fluid organizational features al-Qaeda currently exhibits, this paper argues that al-Qaeda strategically chose to exploit the Internet and other information technologies in order to overcome its organizational and tactical limitations. This exploitation of information technology has led to the widespread and unfiltered transmission and reception of its ideological principles. Although recent cases demonstrate the emergence of "Ione wolves" radicalized by al-Qaeda's Internet activities, the broader ramifications of al-Qaeda's exploitation of the Internet and other technologies for mass mobilization and operational considerations remain unclear.

Since the end of the Cold War, the world has witnessed the emergence of non-state actors as pivotal players in the international arena. These non-state actors include national and transnational criminal organizations, national and transnational non-governmental organizations concerned with human and minority rights, and netforces. ${ }^{1}$ The latter two groups consists of actors who are committed to the advancement of certain principles or ideologies and attempt - through rhetoric, litigation, violence, politics, reporting, propaganda, and other means - to compel other social actors (including other nonstate actors) to assist in or avoid obstructing the realization of these goals. These actors act within certain geopolitical contexts and must respond to actions by other actors that either constrain or support their respective causes. Paralleling the emergence of these non-state actors is the rapid advancement and proliferation of information technologies that provide social actors with new avenues to further their cause. This paper will analyze the changing organizational structure of one such non-state actor, the terrorist network al-Qaeda, and then proceed to assess how al-Qaeda's current organizational structure influences its use of information technology recruit, and attack its targets. It will conclude with a discussion of the implications of these findings for al-Qaeda's activities.

Overview and Conceptualization of al-Qaeda's Organizational Transformations

Al-Qaeda ("The Base") originated in the late 1980s with the expressed purpose of engaging in jihad (defined by al-Qaeda as the violent, theologically-driven struggle against anti-Islamic or un-Islamic forces) against Western influences that were regarded as polluting the ummah (the global Muslim community) and corrupting Muslim governments. Its ultimate goal was to restore the transnational Caliphate (Fishman 20). Al-Qaeda is the successor to the Services Office, which was "a clearinghouse for the (primarily the Internet) to spread its ideology, 